\title{
The Hearing Loss That Pulsates
}

\author{
Pulsatil Tarzda Işsitme Kaybı
}

\author{
Nadhirah Mohd SHAKRI $\odot$, Asma ABDULLAH $\odot$, Noor Dina HASHIM $\odot$, Rozman ZAKARIA $\odot$, \\ Zakhirati Zainol ABIDIN ${ }^{\oplus}$, Suria Hayati Md PAUZI ${ }^{\oplus}$, Noor ain Mohd NASIR ${ }^{\circledR}$
}

Ethics Committee Aproval: Not Applicable.

Confillict of Interest: The authors declare that they have no conflict of interest. Funding: None.

Informed Concent: Informed consent was taken.
Cite as: Shakri NM, Abdullah A, Hashim ND, et al. The hearing loss that pulsates. Medeniyet Med J. 2019;34:218-22.

\begin{abstract}
Glomus jugulare tumor arises within the jugular foramen with close proximity to lower cranial nerves and major vessels. The aim of treatment is complete resection of tumor with preservation of cranial nerves. However, surgery carries high morbidities and challenging especially in large tumors. A 47-year-old woman experienced hearing loss followed by pulsatile tinnitus for 2 years. Upon a thorough examination and investigations, she was later diagnosed with glomus jugulare. Tumour was excised through transmastoid approach and residual tumour was left at surgery to prevent potential morbidities. She received adjuvant stereotactic postoperative radiotherapy. Due to insidious onset, high index of suspicion for glomus tumor is needed to initiate early treatment and reduce morbidity. Thus, tinnitus should not be underestimated. Combination of partial resection with postoperative radiotherapy is the most suited and effective treatment in large tumors with preservation of the function of cranial nerves. Routine postoperative MRI is beneficial to monitor residual and recurrence.
\end{abstract}

Keywords: Glomus jugulare, computed tomography, magnetic resonance imaging, angiogram öz

Glomus jugulare tümörü, juguler foramen içinden çıkmakta olup, alt kranyal sinirler ve ana damarlar ile çok yakın ilişki içindedir. Tedavisinde amaç kranyal sinirleri koruyarak tümörün tam rezeksiyonudur. Ancak özellikle büyük tümörlerde cerrahi yüksek morbiditeye sahip olup zorlayıcı olmaktadır. Kırk yedi yaşında bir kadın hasta 2 yıl süreyle pulsatil tinnitusun takip ettiği bir işitme kaybı yaşamıştır. Ayrıntılı bir muayene ve tetkikler sonrasında glomus jugulare tanısı almıştır. Potansiyel morbiditeleri önlemek için rezidü tümör bırakılarak tümör transmastoid yaklaşımla çıkarılmıştır. Hasta postoperatif olarak adjuvan stereotaktik radyoterapi almıştır. Sinsi başlangıca sahip olması nedeniyle, tedaviyi erkenden başlatmak ve morbiditeyi azaltmak için glomus tümöründen yüksek oranda şüphelenmek gereklidir. Bu nedenle tinnitus hafife alınmamalıdır. Postoperatif radyoterapi ile birlikte tümörün parsiyel rezeksiyonu şeklindeki kombine modaliteler, kranyal sinir fonksiyonlarının korunmasını sağlayarak büyük tümörlerin tedavisinde en uygun ve etkili yöntem olmaktadır. Rutin postoperatif $M R$ görüntüleme, rezidü ve rekürrensi izlemek için yararlı olmaktadır.

Anahtar kelimeler: Glomus jugulare, bilgisayarlı tomografi, manyetik rezonans görüntüleme, anjiyogram
Received: 14.10 .2018

Accepted: 27.11 .2018

Online First: 10.06 .2019

Corresponding Author: A. Abdullah

ORCID: 0000-0002-0103-8858 Universiti Kebangsaan Malaysia Medical Centre, Department of Otorhinolaryngology - Head \& Neck Surgery, Kuala Lumpur, Malaysia nadhirahshakri@gmail.com

N.M. Shakri ORCID: 0000-0003-4939-2562 N.D. Hashim ORCID: 0000-0002-1366-6202 Universiti Kebangsaan Malaysia Medical Centre, Department of Otorhinolaryngology - Head \& Neck Surgery, Kuala Lumpur, Malaysia

R. Zakaria ORCID: 0000-0002-3478-7687 Z.Z. Abidin

ORCID: 0000-0001-9547-0360 Universiti Kebangsaan Malaysia Medical Centre, Department of Radiology, Kuala Lumpur, Malaysia

S.H. Md Pauzi ORCID: 0000-0001-5845-0061

N.ain M. Nasir ORCID: 0000-0002-6525-6678 University Kebangsaan Malaysia Medical Centre, Department of Pathology, Kuala Lumpur, Malaysia 


\section{INTRODUCTION}

Glomus jugulare is a slow-growing hypervascular tumor which is often discovered late due to its insidious onset of symptoms ${ }^{1}$. Typically, glomus jugulare occurs between 50 to 60 years of age, predominantly in females ${ }^{2}$. They originate within the wall of the jugular bulb from the paraganglia called the glomus bodies and often involves the cranial nerves and it may extend to the middle ear $^{2}$. Pulsatile tinnitus and decrease in hearing are the most common presenting symptoms ${ }^{3}$. With the recent advances in techniques, surgical resection with preoperative embolization has been the mainstay of treatment; however preservation of cranial nerve remains a challenge $e^{4,5}$. Combination of surgery and postoperative radiotherapy has been suggested as the most effective option/management in cases of large glomus tumor with intact cranial nerves ${ }^{6}$.

\section{CASE REPORT}

A 47-year-old woman presented with pulsatile hissing sound in the left ear accompanied with hearing loss that was progressively worsening in the duration of 2 years. The patient also had intermittent blood stained left ear discharge and left dull temporal headache persisting for 1 year. However, there were no signs of vertigo or facial weakness. She denied difficulty in swallowing, hoarseness, palpitation or tremors. Otoscopic examination revealed space-occupying lesion in the left external auditory canal which was obscuring the tympanic membrane. Tuning fork tests showed Rinne-negative result on the left side and Weber's test lateralized to the left ear which suggested conductive hearing loss of the left ear. Pure-tone audiometry (PTA) was performed that revealed left mild to moderate conductive hearing loss at low frequencies and moderate to severe mixed hearing loss at high frequencies. Vanilylmandelic (VMA) and serum cortisol levels in 24-hour urine samples were within normal limits.
The computed tomography (CT) scan showed destruction of the left posterior petrous apex and

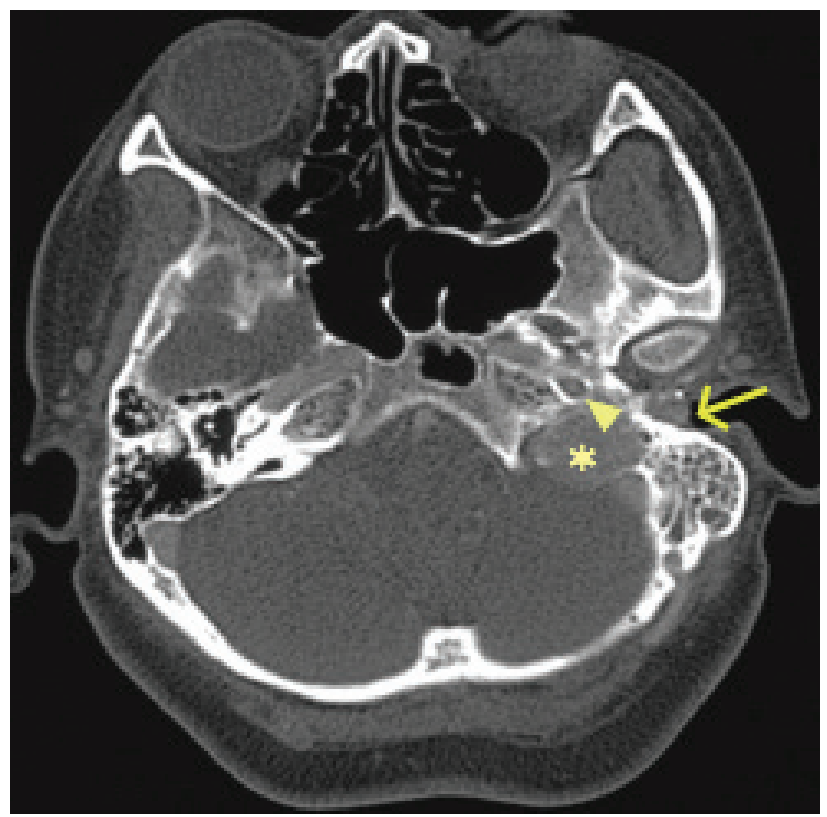

Figure 1. CT scan in bone window shows a soft tissue tumour at the jugular fossa (asterisk) extending to the middle ear and external acoustic canal (arrow) with destruction of the jugular foramen and posterior petrous apex, and erosion of the posterior wall of the carotid canal (arrowhead).
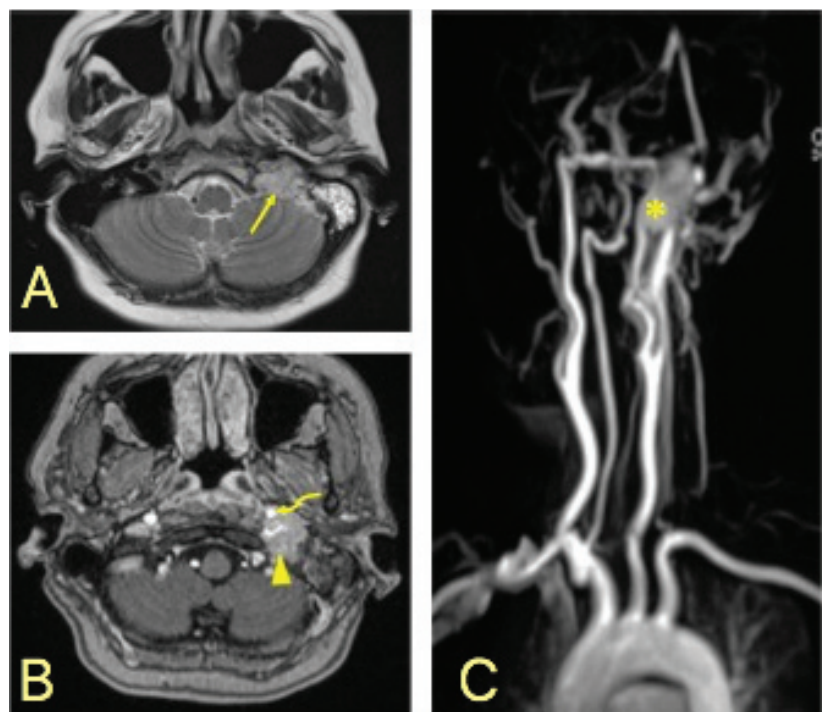

Figure 2. MRI demonstrated hyperintense left jugular fossa soft tissue tumour with flow void signals within (arrow) (A) which enhanced intensely on post-contrast sequence (arrowhead) (B). Note that the petrous part of the left internal carotid artery was encased by the tumour (curved arrow). On MRA there was enhancement of the tumour and its surrounding vasculature (asterisk) (C). 
mastoid region near the jugular foramen with erosion of the posterior wall of the carotid canal. An enhancing soft tissue mass with its epi-centre at the jugular fossa extended to the middle ear and external acoustic canal, and inferiorly to infratemporal fossa was observed (Figure 1). On magnetic resonance (MR) imaging the mass demonstrated high signal intensity on T2-weighted images with flow- void signals within and enhancement of the vasculature and the mass on MR angiography, both of which indicated a highly vascularised tumor. Intense enhancement following intravenous contrast administration, and encasement of the petrous part of the internal carotid artery were clearly depicted (Figure 2). There was no extension to the adjacent left middle temporal fossa or to the nasal cavity anteriorly. The CT and MR characteristics were consistent with glomus jugulotympanicum. On this basis, diagnosis of nonsecretory glomus jugulotympanicum was made. As per the classification devised by Ficsh, the tumor was type $\mathrm{C} 1$.

The patient was treated with excision of tumor with extended posterior tympanostomy through transmastoid approach One day prior to operation, patient underwent angioembolization of the tumor. The initial digital subtraction angiography (DSA) showed intense tumor blush with dilated and prematurely draining veins due to intratumo-

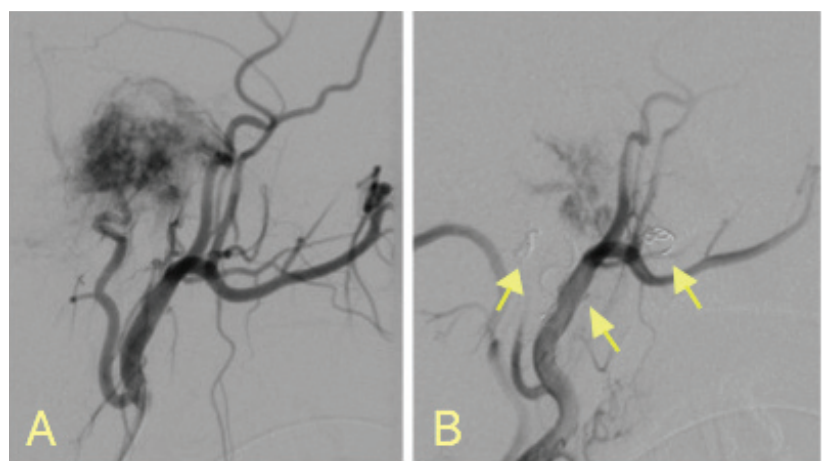

Figure 3. DSA of the left external carotid artery on lateral projection showed intense tumour blush and vessels supplying the tumour; posterior auricular artery (hyperthrophic), ascending pharyngeal artery and small branch of the left internal maxillary artery (A). $80 \%$ reduction of the tumour blush demonstrated post-embolization with particles and coils (B). ral shunting. Vessels supplying the tumor including the left posterior auricular artery, ascending pharyngeal artery and small branch of internal maxillary artery, were super-selectively cannulated and embolized with particles (polyvinyl alcohol) and coils causing $80 \%$ reduction of the tumor blush (Figure 3).

She was operated under general anesthesia in supine position and facial nerve monitoring was applied. C-shaped postauricular skin incision was made until periosteum and anterior based flap was raised. Mastoid bone was drilled posteriorly to sigmoid sinus, anteriorly to posterior external auditory canal (EAC), inferiorly to mastoid tip and superiorly to the temporal line. Cortical mastoidectomy was performed followed by extended posterior tympanostomy with removal of incus and head of malleus. A mass arising from jugular bulb occupied the middle ear extending to the sigmoid sinus. The part of the tumor extending into the EAC and middle ear was removed via transmeatal approach however the tumor at the jugular bulb and sigmoid sinus were left untouched during the surgery due to the risk of bleeding and its close proximity to the lower cranial nerves. Hemostasis was secured with bone wax and

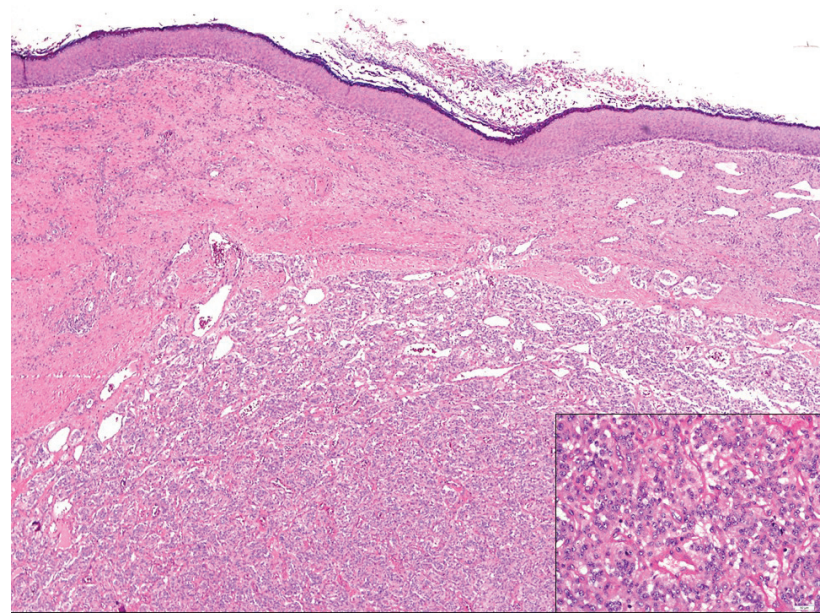

Figure 4. The circumscribed subepithelial tumour is arranged in zellballen (nesting) pattern separated by thin fibrovascular septa (H\&E, 4x). Insert shows higher magnification of the tumor cells displaying uniform round nuclei and abundant granular cytoplasm with flattened sustentacular cells at the periphery of the nests (H\&E, 40x). 
adrenaline soaked gelfoam. Tympanoplasty with underlay technique using temporalis fascia graft was performed. Mastoid cavity was closed with temporalis fascia graft and anterior based flap. Post-auricular wound was sutured and mastoid bandage applied.

The postoperative histopathology reported circumscribed subepithelial tumor arranged in zellballen pattern surrounded by substentacular cells and thin fibrovascular septa. The chief cells exhibit salt and pepper nuclei with moderate amount of granular cytoplasm. Immunohistochemistry studies have showed that the chief cells were positive for synaptophysin and the sustentacular cells were positive for $\mathrm{S} 100$, so the diagnosis of glomus tumor was made (Figure 4).

Postoperatively, all the cranial nerves $(\mathrm{CN})$ were intact except for 8th cranial nerve. Due to partial resection of the tumor, she underwent postoperative adjuvant stereotactic radiotherapy.

\section{DISCUSSION}

Glomus jugulare arises from neuroectodermal tissues in the region of jugular bulb with close proximity to the lower cranial nerves and major vasculature $^{1}$. The vascularized tumor tends to be benign but can be locally aggressive. It may also extend to the middle ear ${ }^{2}$. Being predominantly in women, it is also mostly diagnosed in between $50-60$ years of age $^{2}$. The reported incidence of functioning glomus jugulare is $2-4 \%{ }^{7}$. Functioning tumors produce catecholamines, noradrenaline or dopamine resulting in a clinical picture similar to phaeochromocytoma characterized with hypertension and tachycardia ${ }^{7}$. Ten to fifty percent of paragangliomas are hereditary and malignancy is seen in $10 \%$ of the cases ${ }^{7}$. The incidence of multiple lesion is reported to be between 25 to $50 \%$ in familial cases, compared with less than $10 \%$ in sporadic cases ${ }^{2}$.

Patients commonly present with insidious onset of pulsatile tinnitus and hearing loss ${ }^{3}$. The classi- cal pulsating red postero-inferior segment of the tympanic membrane or rising sun appearance with conductive hearing loss are the most frequent clinical signs ${ }^{3}$. Blood stained ear discharge is commonly seen in an advanced stage when the tumor extends beyond the tympanic membrane ${ }^{3}$. Extension to the inner ear produces vertigo and sensorineural hearing loss. The presence of jugular foramen syndrome which is paresis of cranial nerves IX to $\mathrm{X}$ is pathognomic for this tumor ${ }^{3}$.

A combination of CT scan and MRI performed with gadolinium-diethylenetriamine pentaacetate (DTPA) administration is recommended to assess the location and extension of glomus tumors ${ }^{4}$. High-resolution CT scan is the best imaging technique to identify the paragangliomas and evaluate bone invasion while MRI is excellent in delineating the soft tissue characteristics and extension of the tumor $^{4}$. Typically, the tumor shows a characteristic 'salt-and-pepper' pattern which intervenes with high and low signals due to bleeding and highflow vessels respectively. Another important imaging is MRA which provides excellent visualization of the major vasculature, vessel displacement and potentially compromised blood flow ${ }^{4}$.

Up to date two main modalities of treatment namely surgery and radiation exist. However, surgery is still extremely challenging because of the high risk of morbidity due to complications such as cranial nerve injury, vascular injury and injury to the carotid body or carotid sinus complex ${ }^{4,5}$. Complete resection with conservation of cranial nerves is the ultimate goal of contemporary surgery applied for glomus jugulare tumors. The probabilities that need to be considered when deciding the treatment for these patients are the patients' age and health status, tumor location and size, the status of the lower cranial nerves at the moment. Total surgical resection may be possible in cases which the function of the lower cranial nerves has been compromised, provided that the medical condition of the patient allows it. However, in the presence of a large tumor, even though the function 
of the cranial nerves is preserved, partial resection with adjuvant radiotherapy is recommended to prevent devastating lower cranial nerve deficits and to reduce potential morbidity associated with carotid artery injury ${ }^{6}$. Monotherapy with radiotherapy should be offered in a tumor involving skull base or had intracranial extension ${ }^{5}$. Studies have reported that radiotherapy is effective in providing less iatrogenic effects with equivalent tumor control rate as compared to surgery ${ }^{8,9}$.

Preoperatively embolization of cervical region paragangliomas 48 hours prior to surgery is reported to reduce intraoperative blood loss and operating time $\mathrm{e}^{10,11}$. The reason for the intentional delay of 1-2 days between embolization and surgery is to allow time for edema to resolve without providing time for reconstitution or recruitment of feeding arteries ${ }^{10}$. Complications of preoperative embolization includes stroke which may occur due to accidental entry of emboli into the vertebrobasilar system via the external carotid artery (ECA) or its anastomoses with the internal carotid artery (ICA) ${ }^{12}$.

The incidence of recurrence in glomus jugulare is reported to be $7.8 \%$ occurring between 3 years to 9 years post primary treatment ${ }^{13}$. Routine postoperative MRIs obtained at intervals of 1,3 , and 5 years with subsequent scans at 5-year intervals are beneficial to monitor any residual or recurrent tumor $^{13}$.

\section{CONCLUSION}

Pulsatile tinnitus should not be taken lightly as it can be a symptom of glomus jugulare tumor. High index of suspicion may help instigate early diagnosis and treatment, thus eventually minimizing morbidity. Combined modalities of partial resection of tumor with postoperative radiotherapy are the most suited and effective treatment in large tumors with preserved function of cranial nerves. Routine postoperative MRI is beneficial to monitor residual tumor and recurrence, if any.

\section{REFERENCES}

1. Ahmad M, Malik IM, Siddiqui A, Malik AM. Glomus jugulare: high index of clinical suspicion is important for optimal management. BMJ Case Rep. 2013; 2013. [CrossRef]

2. Chung SM, Kim HS, Jung J, Lee H-K, Lee WS. Clinical presentation and management of jugular foramen paraganglioma. Clin Exp Otorhinolaryngol. 2009;2:28-32. [CrossRef]

3. Kumar K, Ahmed R, Bajantri B, et al. Tumors presenting as multiple cranial nerve palsies. Case Rep Neurol. 2017;9:54-61. [CrossRef]

4. Hu K, Persky MS. Multidisciplinary management of paragangliomas of the head and neck, Part 1. Oncology (Williston Park). 2003;17:983-93.

5. Hu K, Persky MS. Multidiciplinary management of paragangliomas of the head and neck, Part 2. Oncology (Williston Park). 2003;17:1143-61.

6. Fayad JN, Schwartz MS, Brackmann DE. Treatment of recurrent and residual glomus jugulare tumors. Skull Base. 2009;19:92-8. [CrossRef]

7. Young WF. Paragangliomas: clinical overview. Ann N Y Acad Sci. 2006;1073:21-9. [CrossRef]

8. Semaan MT, Megerian CA. Current assessment and management of glomus tumors. Curr Opin Otolaryngol Head Neck Surg. 2008;16:420-6. [CrossRef]

9. Jansen TTG, Timmers HJLM, Marres HAM, Kaanders JHAM, Kunst HPM. Results of a systematic literature review of treatment modalities for jugulotympanic paraganglioma, stratified per Fisch class. Clin Otolaryngol. 2018;43:652-61. [CrossRef]

10. White JB, Link MJ, Cloft HJ. Endovascular embolization of paragangliomas: A safe adjuvant to treatment. J Vasc Interv Neurol. 2008; 1:37-41.

11. Persky MS, Setton A, Niimi Y, Hartman J, Frank D, Berenstein A. Combined endovascular and surgical treatment of head and neck paragangliomas-A team approach. Head Neck. 2002;24:423-31. [CrossRef]

12. Tasar M, Yetiser S. Glomus tumors: therapeutic role of selective embolization. J Craniofac Surg. 2004;15:497-505. [CrossRef]

13. Gjuric M, Gleeson M. Consensus statement and guidelines on the management of paragangliomas of the head and neck. Skull Base. 2009;19:109-16. [CrossRef] 